\title{
Regulasi Memori dalam Pengarsipan Rekonstruksi Sejarah
}

\author{
Harfiyah Widiawati
}

\begin{abstract}
Writing and documentation involve a process of selection and arrangement. Archives; therefore, is a system which organize the documentation of writings, documents and notes. Archives become a structure that organizes memories because of their close ties with the past. Archives legitimize and control the history of mankind. This article seeks to discuss how archive system can reconstruct or construct history of a nation and the relationship between power and archive system. Supersemar is a concrete example of how power constructs a political history regulated for New Order rezime's interests.
\end{abstract}

KATA KUnCl Arsip, regulasi memori, sejarah, politik.

\begin{abstract}
A SONNET TO ARCHIVY
As barren fields in wintertime are lined With broken stalks and ears of corn long spent, So records are the stubble of mankind They have no life, and give no nourishment. They are the words and numbers of the past, The dry misshapen kernels in the bran, Like chaff stripped from the germ, they cannot lastYet you do make them feed the mindof Man. Then hearty, golden grains these records be: They are the endless grist of History.
\end{abstract}

Thomas Michael McCort (1982)

Pengarsipan sebagaimana yang diperikan dalam soneta tersebut adalah sebonggol jagung, bijih kacang yang buruk dalam kulitnya: ia hadir dari ampas dan sisa-sisa kehidupan manusia; ia mencatat huruf dan angka dari kejadian yang menimpa manusia. Akan tetapi, seberapa pun tak tersadari dan terabaikan, pengarsipan tetaplah sumber sejarah yang takberkesudahan. Orang seringkali memahami kegiatan pengarsipan sekadar kegiatan administratif yang mengatur dokumen-dokumen ke dalam suatu susunan yang lebih sistematis sehingga pada saat diperlukan dokumen 
tersebut dapat dicari dan diakses dengan cepat. Banyak yang tidak menyadari bahwa fungsi arsip tidak sekadar memenuhi kebutuhan akan informasi tertentu, tetapi juga menciptakan sebuah memori sejarah yang di dalamnya identitas seseorang atau kelompok terakomodasi, terbentuk, dan terkukuhkan. Seperti digambarkan dalam soneta yang telah dikutip, kehadiran dan keberadaan arsip sepertinya remeh, padahal ia mempunyai peran yang sangat penting dalam kehidupan manusia; ia mengorganisasi memori dan menciptakan sejarah. Dalam proses produksinya, pengelolaan arsip menjadi sebuah kegiatan yang problematik, bukan hanya karena ia memproduksi memori yang memberikan identitas politik, ekonomi, dan sosial pada individu atau kelompok masyarakat tertentu, melainkan juga karena, dalam interelasinya dengan bidang lain, ia mempunyai peranan yang signifikan dalam menentukan keberadaan dan kepentingan historis entitas lain tersebut. Sebuah studi kasus terhadap Surat Perintah Sebelas Maret (Supersemar) akan memerikan problematika yang melingkupi regulasi memori dalam kegiatan kearsipan. Studi kasus ini akan menjadi contoh konkret atas kekuasaan pengarsipan dalam merekonstruksi sejarah sebuah bangsa. Sebelum membahas problematika kearsipan, terlebih dahulu dibahas asal mula kearsipan untuk memberikan batasan yang jelas mengenai apa yang dimaksud dengan kegiatan kearsipan itu sendiri.

\section{Arsip: Sebuah Batasan}

Yang dimaksud dengan arsip menurut Undang-Undang no. 7 tahun 1971 adalah pertama, naskah-naskah yang dibuat dan diterima oleh lembagalembaga dan badan-badan pemerintahan dalam bentuk corak apa pun, baik dalam keadaan tunggal maupun berkelompok dalam rangka pelaksanaan kegiatan pemerintahan; kedua, naskah-naskah yang dibuat dan diterima oleh badan-badan swasta atau perorangan, dalam bentuk corak apa pun, baik dalam keadaan tunggal maupun berkelompok, dalam rangka pelaksanaan kehidupan kebangsaan.

Undang-undang tersebut tampak membedakan arsip berdasarkan fungsinya, yaitu arsip dinamis (record), yang dipergunakan secara langsung dalam administrasi negara, dan arsip statis (archieve) yang tidak dipergunakan secara langsung dalam kehidupan kebangsaan (Amsyah 1995: 2). Batasan tersebut merujuk pada sesuatu yang sudah sangat spesifik, yaitu konteks berbangsa dan bernegara. Secara umum, dalam bahasa Inggris sendiri terdapat dua kata yang melabeli kedua jenis dokumen, yaitu record dan archieve, sementara dalam bahasa Belanda hanya ada satu istilah, archief. Untuk memahami secara lebih umum mengenai naskah, catatan, dan dokumen itu sendiri ada baiknya kita kembali ke akar kata yang membangun record. Record berasal dari gabungan kata latin cor yang berarti 'hati', dan dare yang artinya 'memberi'. Jadi re-cor-dare berarti 'mencari cara untuk memberi jalan kembali ke hati dan pikiran setelah beberapa waktu berselang' (to find a way to give it back to the heart and the mind after the passage of time [O'Toole 1990: 8]). Frasa "memberi kembali ke pikiran" 
(memorare) memberikan rujukan pada penyimpanan ingatan atau memori yang dapat dibantu dengan pencatatan, karena ingatan manusia sendiri terbatas. Dengan tulisan, orang dapat menyimpan dan mengingat informasi-informasi penting untuk digunakan bagi keperluan yang berbeda-beda.

verba volent, littera scripta manet words are fleeting, written letters remain

(Horace)

\section{TUlisan dan MEMORI}

Tulisan (writing) merupakan hasil kebudayaan yang muncul setelah ujaran (speech). Kemampuannya untuk menyimpan informasi melampaui kemampuan ingatan yang disampaikan secara turun-temurun lewat budaya oral. Pada awal peradaban dunia, pengetahuan disampaikan secara lisan. Dongeng, nyanyian, mantera, dan sebagainya, disebarkan dari mulut ke mulut. Satu-satunya tempat penyimpanan untuk semua "teks" tersebut adalah benak manusia. Seluruh anggota masyarakat yang melestarikan tradisi oral memiliki benak kolektif yang menampung teks dan pengetahuan 'words of mouth' tersebut ( $\mathrm{O}^{\prime}$ Toole 1990: 7). Keuntungannya ialah anggota masyarakat dapat saling bertanya satu sama lain hingga pemahaman maksimal dapat tercapai. Kerugiannya, sebuah komunikasi oral eksis hanya ketika percakapannya berlangsung; setelah itu ia mati. Selain itu, kapasitas ingatan atau benak seseorang itu terbatas, orang tidak dapat pula terlepa: dari ketaksempurnaan memori manusia. Seberapa baik pun orang mengingat sesuatu, tetap masih ada detail yang luput. Karena itu ada kebutuhan untuk mengembangkan memori manusia. Salah satu cara yang ditempuh adalah dengan menciptakan simbol, tulisan. Lewat tulisan, informasi dapat disimpan dalam bentuk yang lebih tetap dan akurat. Tulisan memungkinkan pengetahuan yang lebih obyektif dibandingkan dengan pengetahuan subyektif yang dimiliki lisan. O'Toole (1990: 8) menyatakan "Literacy preempted orality, replacing it as a more efficient and effective means for information storage, transfer, and use."

Seperti yang telah diperikan Horace, lisan berlalu, sedangkan tulisan tinggal. Begitu diucapkan, bahasa lisan langsung menguap, tidak bisa dihadirkan kembali sementara tulisan meninggalkan jejak-jejak yang dapat ditelusuri kembali. Tulisan juga meniadakan jarak: waktu dan tempat. Melalui tulisan orang dapat mengarungi waktu, kembali ke masa lalu, atau sekaligus juga menciptakan masa depan. Selain itu orang dapat "mengunjungi" tempat-tempat yang jauh tanpa harus keluar dari ruang baca. Dalam studi sejarah, munculnya tulisan menandai pergeseran dari zaman prasejarah ke sejarah. Tulisan juga telah menggeser struktur masyarakat, dari masyarakat mengingat (remembering society) ke masyarakat baca-tulis. Dalam masyarakat baca-tulis ini tulisan menjadi 
penting peranannya karena ia dapat menjadi dokumen pembukti. Reliabilitas, keabsahan, dan pembuktian kini lebih bergantung pada tulisan dan pencatatan daripada ingatan seseorang. Dengan demikian, tulisan menjadi semacam artefak bagi memori, yang keabsahan dan akurasinya bernilai lebih tinggi daripada lisan seseorang (O'Toole 1990: 8).

Seseorang membuat tulisan, melakukan pencatatan karena didorong oleh berbagai hal, di antaranya karena ia tidak mau masa kini berlalu begitu saja; ia ingin mendokumentasikan apa yang terjadi di masa kini dengan harapan bahwa suatu saat dokumen tersebut akan berguna. Karena itu, sebuah dokumen, menciptakan memori tertentu. Inilah mungkin yang menjadi keterbatasan tulisan: ia tidak bisa merekam suatu fenomena secara keseluruhan, sebagaimana ingatan manusia memahami fenomena tersebut. Tulisan dan pencatatan merupakan sebuah proses seleksi, sebuah pengaturan. Proses pengaturan tulisan inilah yang menandai kegiatan pengarsipan.

\section{Arsip dan Memori}

Mengapa orang menyimpan catatan? Jenis-jenis informasi apakah yang layak untuk dicatat dan disimpan? Pertanyaan-pertanyaan semacam ini membawa orang untuk berpikir lebih dalam mengenai kearsipan. Setiap orang dapat membuat catatan dan menyimpan informasi yang dianggapnya penting selama hidupnya seperti surat lahir, foto, catatan pengeluaran, ijazah, dan catatan harian. Jika setiap orang melakukan hal yang sama, dapat dibayangkan betapa banyak ruang yang harus disisihkan untuk menampung catatan dan dokumentasi tersebut. Selain itu, catatan dan dokumen tersebut harus diatur, dikategorisasi sehingga pada saat dibutuhkan dapat segera diakses. Arsip, dengan demikian, menjadi sebuah sistem yang mengatur penyimpanan tulisan, dokumen, dan catatan. la menjadi sebuah struktur yang mengorganisasi memori. Seperti halnya bahasa yang menstrukturkan taksadar manusia, arsip menstrukturkan dan membentuk memori. Bila taksadar dapat dipahami melalui manifestasi bahasa, maka kehidupan dan identitas manusia pun dapat lebih dipahami melalui manifestasi memori. Akan tetapi, yang penting dari memori itu sendiri bukan teks yang membentuknya melainkan proses pembentukan teks itu sendiri karena menurut O'Toole (1990: 10):

meaning emerged from the whole rather than from any one part, [as a result] the key single document that would answer every question was less meaningful than the totality of recorded information and the processes that had produced it.

Persepsi ini membawa kita untuk memfokuskan pada momen produksi yang melingkupi arsip.

Sejak empat milenium sebelum masehi, arsip telah diciptakan. Dikatakan oleh O'Toole (1990: 28):

[F]rom Babylonian tablets to Egyptian papyri to Greek and Roman wood blocks and parchments[,] archival records were produced by government and other officials bodies, and they were preserved because of their lasfing official and administrative usefulness. 
Arsip-arsip tersebut telah menjadi bukti langsung akan keberadaan dunia asalnya, they are prototypical examples of the connections between records, and the processes of life that produce them (Posner 1972). Kaitan antara arsip dan kehidupan sangatlah jelas: acts and deeds meant not only the things that particular people had done at particular times, but also denoted the written records which affirmed that those things had been done (Taylor 1988: 456-69). Arsip merefleksikan kehidupan manusia pada masanya. Arsip menurut O'Toole (1990: 29) "sought to preserve systematically the evidence of the past, perhaps in the interest of promoting historical understanding, perhaps out of a desire to show how much progress had been made." Arsip sangat erat kaitannya dengan memori masa lalu; ia memberikan gambaran tentang masa yang diabadikannya; ia menciptakan legitimasi dan kontrol atas sejarah manusia. Kemampuan semacam itulah yang membuat arsip begitu "digemari" oleh (kelompok) orang yang ingin menguasai memori sejarah dan masa lalu. Salah satu ilustrasi yang komprehensif akan diperoleh jika kita menganalisis sebuah dokumen yang banyak menimbulkan kontroversi, yakni Surat Perintah Sebelas Maret.

\section{Supersemar dan Memori}

Surat Perintah 11 Maret 1966 atau yang dikenal dengan Supersemar adalah dokumen yang dikeluarkan oleh Presiden Soekarno yang isinya memberikan keleluasaan kepada Mayor Jenderal Soeharto untuk menumpas orang-orang yang terlibat peristiwa G-30-S/PKI (Gerakan 30 September 1965/Partai Komunis Indonesia). Penumpasan itu menyebabkan "banjir darah yang menewaskan antara 500.000-1.000.000 rakyat Indonesia, sekitar 700.000 orang ditangkap dan disiksa tanpa proses hukum" (Tobing 2001). Naskah surat itu pula yang akhinya dipakai oleh MPRS (Majelis Permusyawaratan Rakyat Sementara) ketika itu sebagai patokan untuk menerbitkan sejumlah ketetatapan MPRS dan pegangan pengangkatan Soeharto sebagai presiden (Kompas, 17 Maret 2000). Surat perintah itu menjadi begitu penting dan problematik karena naskah asli yang sedianya disimpan oleh pihak Arsip Nasional ternyata hilang dan tidak pernah ditemukan. Ada dua versi yang beredar ${ }^{1}$ selama ini di kalangan masyarakat, yaitu versi yang diterbitkan Sekretariat Negara (Setneg) dan versi Dinas Penerangan Angkatan Darat. Dalam kedua versi tersebut terdapat 23 butir perbedaan (Kompas, 16 Februari 2000), ${ }^{2}$ versi yang satu antara lain mengatakan "harus diadakan koordinasi dengan panglima angkatan-angkatan," dan versi lainnya mengatakan "panglima-panglima angkatan" (Kompas, 5 Mei 2001). Walaupun perbedaannya hanya dalam kata yang diulang, perbedaan itu

Artikel lain mengatakan bahwa yang beredar adalah empat versi dokumen Supersemar baik dengan atau tanpa tanda tangan Presiden Soekarno. Di antaranya adalah dua naskah Supersemar menurut versi buku 30 Tahun Indonesia Merdeka terbitan Sekretariat Negara dan satu naskah lain terbitan Pusat Penerangan Angkatan Darat (Kompas, 17 Maret 2000)

Artikel lain menyebutkan ada 25 perbedaan. 
menjadi fatal karena menggoyah atau bahkan menggugurkan otentisitas dokumen-dokumen tersebut.

Karena berkaitan dengan peristiwa sejarah Indonesia, hilangnya naskah asli ini menjadi problema bagi banyak pihak, misalnya pihak Arsip Nasional Republik Indonesia (ANRI). Kepala ANRI, Dr. Mukhlis PaEni merasa berkepentingan, ia ingin melacak dan menemukan naskah penting itu, dan upaya itu bukan sekadar "untuk urusan pengarsipan, urgensi itu dilatarbelakangi oleh kebutuhan menguak momen-momen awal sejarah lahirnya Orde Baru yang kini masih disaput misteri" (Kompas, 17 Maret 2000). Naskah asli Supersemar merupakan artefak sejarah, keberadaannya menjadi simbol legalitas kekuasaan Jenderal Soeharto. Hilangnya secarik kertas yang menandai "keabsahan" rezim Orde Baru itu membuka jalan bagi orang untuk mempertanyakan kembali semua memori masa lalu yang telah diregulasikan dengan cerdiknya oleh Soeharto selama 32 tahun kekuasaannya; memori yang menyatakan bahwa pembantaian massal 1965-66 merupakan upaya yang benar-benar harus dilakukan untuk menyelamatkan stabilitas negara, dan sekaligus juga memori yang menciptakan kisah kepahlawanan Soeharto hingga ia layak diangkat menjadi presiden Republik Indonesia.

Mengutip Thompson (1997: 2), dapat dilihat bahwa Supersemar, merupakan artefak memori, artefak budaya "has an impact upon the regulation of sociallife through the ways in which it is represented, the identities associated with it, and the articulation of its production and consumption." Untuk melihat lebih jelas mengenai regulasi ini, saya akan menyediakan poin khusus yang akan dibahas secara khusus dalam bagian selanjutnya.

Rezim Memori: Sejarah yang Diregulasikan

Arsip merupakan rekaman sejarah suatu bangsa. Intervensi yang terlalu banyak dari pihak penguasa, terutama yang represif, mengindikasikan pengelolaan arsip yang diregulasikan untuk menyokong kepentingan rezim itu. Rezim represif biasanya tidak memberi tempat pada arsip-arsip yang plural dan variatif sudut pandangnya. Kepentingan untuk melestarikan kekuasaannya membuat rezim tersebut memberlakukan kontrol yang ketat terhadap kegiatan pengarsipan. Lewat badan intelijen dan keamanannya, suatu rezim "menyusun kerangka dokumentasi yang handal, lengkap, dan terjaga dengan baik" (Ratnawati 2002) untuk kemudian menekan perjuangan demokrasi yang membahayakan kekuasaannya. Dalam studi UNESCO tentang pengarsipan pada beberapa pemerintahan represif, ditemukan bahwa ada tiga tipe tindakan terhadap
dokumen (Ratnawati 2002).

- Negara menyimpan lengkap semua format arsip kegiatan badan keamanan selama rezim prademokrasi, misalnya dalam kasus Jerman
dan Spanyol.

- Negara menggunakan dokumen untuk keperluan administratif dan kemudian melenyapkannya dengan alasan etika, misalnya dalam kasus Yunani. 
- Negara tidak memiliki catatan apa pun, setidaknya mereka tidak mengetahui keberadaannya, misalnya dalam kasus Chili.

Dalam kasus Supersemar di Indonesia, tampaknya rezim Soeharto mengikuti pola yang ditawarkan oleh tipe kedua. Dokumen Supersemar awalnya digunakan untuk kepentingan administratif, yaitu untuk melegalkan pembantaian massal tahun 1965-66 sekaligus untuk menyingkirkan lawan-lawan politik yang akan menghalangi jalan Soeharto menuju ke kekuasaan absolut. Surat tersebut mengantarkan pada wacana bahwa peristiwa G-30-S merupakan upaya pengkhianatan terhadap falsafah negara, Pancasila, dan bahwa tindakan pembantaian terhadap orang-orang yang dianggap pengikut PKI merupakan tindakan yang layak dan sudah sepatutnya. Tafsir atas pembantaian itu sebagai sebuah pemberantasan pengkhianatan lalu diperkukuh lagi dengan usaha-usaha lain untuk mempengaruhi MPRS agar menganugerahi tindak kepahlawanan tersebut dengan mencopot jabatan kepresidenan Soekarno dan memberikannya pada Soeharto.

Setelah memperoleh takhta kekuasaan, "pekerjaan rumah" selanjutnya bagi rezim ini adalah meregulasikan tafsir tersebut mulai dari lapis atas pemerintahan hingga pada lapis terbawah masyarakat. Untuk meyakinkan dan mendapatkan dukungan dari lapisan atas, regulasi arsip harus diperketat. Selain membunuh tujuh jenderal lewat aksi PKI, aksi teror pun dilancarkan untuk memusnahkan dokumen-dokumen yang menawarkan tafsir yang berbeda dan mengancam rezim Orde Baru. Aksi penghancuran dan pemusnahan yang paling kentara adalah yang dilakukan terhadap dokumen Jenderal Abdul Haris Nasution yang pernah menjabat sebagai ketua MPRS. Nasution pernah mengatakan kepada Kepala ANRI bahwa dua kopor berisi dokumen pribadinya hilang; kopor dokumen pertama dicuri orang; koleksi dokumen kedua diminta Markas Besar Angkatan Darat (Mabes AD), tetapi tanpa dibuka terlebih dulu, personal file itu langsung dibakar di sana (Wijayanta 2000). Peristiwa itu terjadi pada 1967-68. Arsip Nasional juga telah menelusuri arsip-arsip MPRS kurun waktu 1960-87, namun ada mata rantai naskah (file) yang hilang, terutama semua naskah yang berkaitan dengan kegiatan MPRS pada awal pemerintahan Orde Baru (Kompas, 17 Maret 2000). Mantan Sekjen MPRS, Mayjen (Purn.) Abdul Kadir Besar juga melaporkan hilangnya 110 jilid dokumen mengenai rekaman sejak Komite Nasional Indonesia Pusat (KNIP) Yogyakarta, Konstituante, MPRS Bandung, MPRS Orde Baru dari 1965-68, yang dengan rinci memaparkan upaya Soeharto "mengobok-obok" MPRS agar dalam Sidang Umum MPRS 1968 ia bisa menjadi presiden secara definitif (Kompas, 17 Maret 2000)

Dari segi regulasi memori, tindakan pemusnahan dan penghilangan dokumen itu dapat dipandang sebagai upaya untuk mengatur "a particular pattern and order of signifining practices" (Thompson [ed.] 1997: 3). Praktik pemaknaan dikuasai secara absolut sehingga tafsir yang boleh muncul hanyalah tafsir yang sesuai dengan kepentingan penguasa. Selain itu 
memori yang tidak sesuai dengan memori yang telah dibangun rezim, diabaikan dan bahkan dimusnahkan. Untuk menyamakan ingatan individunya, rezim penguasa harus pula menciptakan strategi yang dapat mengatur benak kolektif masyarakat. Salah satu caranya adalah dengan membangun-yang oleh Foucault disebut-rezine of truth. Truth itu sendiri berpusat pada bentuk wacana ilmiah dan institusi-institusi yang membantu memproduksinya. Aparatus yang menciptakan memori [is] circulating through apparatuses of education and information whose extent is relatively broad in the social body (Foucault dalam Adams [ed.] 1992: 1144). Salah satu strategi yang paling jelas yang dilancarkan Soeharto adalah pemberlakuan Program P4 (Pedoman Penghayatan Pengamalan Pancasila) melalui aparat universitas, institusi militer, tulisan, dan media. Melalui P4, the truth diproduksi untuk dapat melanggengkan kekuasaan Soeharto. Upaya lainnya adalah memasukkan P4 ke dalam kurikulum pengajaran. Mata pelajaran Perjuangan Sejarah Perjuangan Bangsa (PSPB) merupakan upaya untuk menciptakan identitas dan citra positif Soeharto di mata rakyatnya. Selain itu, slogan-slogan seperti "Bapak Pembangunan" diciptakan untuk mengalihkan fokus dari rapuhnya legitimasi kekuasaan yang diciptakannya. Secara politik rezim penguasa menyibukkan masyarakat dengan fokus perhatian yang baru (angka-angka statistik mengenai peningkatan swasembada pangan, peresmian proyek-proyek pembangunan, dsb.) dengan harapan fokus perhatian yang lama (pembantaian sebagai jalur legitimasi akan takhta kekuasaan) dapat terlupakan: memori diarahkan untuk hanya mengakses citra yang positif.

\section{Supersemar dalam Pandangan Global}

Upaya-upaya yang dilakukan untuk merekonstruksi sejarah yang telah diformulasikan oleh rezim penguasa adalah dengan (1) mengumpulkan informasi langsung dari pelaku sejarah, (2) melengkapi arsip dengan mencari dokumen yang hilang, atau (3) mempelajari literatur luar negeri yang bisa lebih terbebas dari kontrol regulasi memori yang dilakukan penguasa. Upaya yang ketiga ini membuka isu sejarah nasional ke wacana global yang menawarkan transformasi our apprehension of the world in sharply contrasting ways. It is provoking new senses of disorientation and orientation, giving rise to new experiences of both placeless and placed identity (Robins [t.t, t.p.?]: 38). Persentuhan dengan literatur luar memungkinkan kasus Supersemar dilihat dari sudut pandang yang berbeda, yang sama sekali lain.

Dipandang secara lokal, aksi "kudeta" yang dilakukan Soeharto terlihat hanya sebagai upaya perebutan kekuasaan oleh salah seorang jenderal. Akan tetapi, bila dipandang secara global peristiwa itu mempunyai makna yang lain yakni merupakan rangkaian perang dingin yang dilancarkan Amerika terhadap berkembangnya komunisme. Dari literatur luar negeri terlihat adanya keterlibatan CIA (Central Intelligence Agency) dalam peristiwa itu. Salah satu buku yang membahas hal tersebut adalah For- 
eign Relations of The United States, 1964-68, Volume XXVI, yang dua bagiannya menguraikan "Coup Counter Reaction: October 1965-March 1966" (128 halaman) dan mengenai "The United States and Suharto: April 1966 -December 1968" (180 halaman).

Bagi pemerintah Amerika sendiri, keterlibatannya dalam G-30-S merupakan sebuah aib karena arsip-arsip yang berkenaan dengannya disimpan dengan rapat kendati telah 36 tahun berla1u. Sementara itu, undang-undang kebebasan memperoleh informasi di AS menyebutkan bahwa batas usia suatu rahasia negara untuk dapat dibuka publik adalah 25 tahun, tetapi hal itu bergantung pada pertimbangan presiden AS. Hal itu menunjukkan bahwa arsip G-30-S dipandang lebih sensitif dibandingkan dengan aktivitas spionase, kontraspionase, dan operasi rahasia yang dilakukan AS di Uni Soviet karena arsip yang berkenaan dengan aktivitas tersebut hampir seluruhnya sudah dibuka (Tobing 2001).

Dilihat dari konteks sejarahnya, pada 1960-an komunisme sedang berkembang dengan pesatnya di Asia, hal ini tentu saja mengancam kepentingan Amerika yang berusaha menguasai dunia dengan konsep kapitalismenya. Ketakutan akan efek domino 4 yang mungkin terjadi, Badan Intelejen AS (CIA) berusaha mendanai agen-agen politik yang dapat diajak bekerja sama untuk membendung arus komunisme tersebut. Jenderal Soeharto tampaknya menjadi orang yang cocok untuk "tugas" itu di Indonesia. Melalui Duta Besar Marshall Green di Jakarta, Washington menyampaikan salam hangat dan dukungan kepada Jenderal Nasution dan Jenderal Soeharto, juga memberikan kesediaan memberikan bantuan termasuk perangkat komunikasi, senjata, kendaraan, obat-obatan (Tobing 2001). Dalam buku Peter Dale Scott, The Overthrow of Sukarno, 1965-67, disebutkan bahwa Kedutaan Besar AS turut serta memberikan ribuan nama kader PKI yang harus dibantai. Sebelumnya, wartawati Cathy Kadane bahkan mengungkapkan bahwa daftar nama tersebut diserahkan Edward Master, Kepala Seksi Politik Kedutaan Besar AS di Jakarta, kepada sekretaris Adam Malik, yang selanjutnya disampaikan kepada Soeharto di markas Kostrad (Tobing 2001).

Dipandang dari segi politik, keterlibatan AS itu merupakan salah satu usaha untuk memenangkan perang dingin. Komunisme dengan paham kerakyatannya akan menghalangi industri-industri Amerika yang menjadi tulang punggung negara tersebut untuk mendapatkan pasar, dan melibatkan negara-negara Asia ke dalam rantai perdagangan yang ingin dikuasainya. Akan tetapi, dalam melaksanakan misinya, AS sangat berhati-hati dengan identitas dan citranya. Negara itu ingin keterlibatannya terlihat dengan jelas. Beberapa wacana bahkan diproduksi untuk menyangkal keterlibatan itu, misalnya lewat disertasi yang ditulis Stig Aga Aandstad di University of Oslo berjudul "Surrounding to Sym-

\footnotetext{
${ }^{3}$ Yang dimaksud efek domino di sini adalah kejatuhan satu negara pada komunisme akan
segera diikuti oleh kejatuhan negara yang lainnya.
} 
bols: United States Policy Towards Indonesia 1961-65," dengan kesimpulan bahwa AS tidak tahu-menahu soal persiapan G-30-S. Bela diri CIA juga diterbitkan dalam buku-buku yang berbeda. Akan tetapi, lewat studi yang komprehensif akan ditemukan beberapa ketaksesuaian dalam informasi yang dipaparkannya (Tobing 2001). Keterlibatan AS dalam peristiwa G-30-S menimbulkan beberapa masalah politik, ekonomi, dan sosial. Karena itu, identitas dan citra AS yang "bersih" pun dibangun supaya tidak ada tuntutan kompensasi dan permintaan maaf. Selain upaya itu juga dimaksudkan untuk menghindari tuntutan dari Mahkamah Internasional bila bukti-bukti yang diajukan cukup kuat.

\section{Pengelolaan Arsip: Konstruksi dan Rekonstruksi Sejarah}

Upaya "melencengkan" sejarah sesungguhnya dapat dibendung bila arsip-arsip kenegaraan dijaga dengan baik. Seperti yang dikatakan Quintana (1997), "archives are the most faithful reflection of the history of a M'ople und thus constitute the most explicit me'mory ofmations." Kesadaran seseorang terhadap pengelolaan arsip mencerminkan kesadarannya akan pentingnya sejarah; karena sejarah menciptakan identitas, maka segala hal yang berkenaan dengannya harus dikelola dengan sebaik-baiknya.

Sejarah merupakan "a deliberate literary effort, relying on literary sources" (O'Toole 1990); karena itu, setiap dokumen, naskah, tulisan, foto, sebagai sumber arsip, perlu dilestarikan. Walaupun jumlah koleksi arsip semakin hari semakin bertambah dan semakin memakan ruang, seleksi dan penyortiran arsip tetap harus dapat memberi wadah bagi sudut pandang yang bervariasi. Sejarah yang biasanya berkenaan dengan orang-orang "besar" sudah sepatutnya diimbangi oleh sejarah mengenai orang-orang "kecil". Peristiwa G-30-S, misalnya, akan sangat menarik jika dibahas dari kacamata kehidupan sehari-hari, seperti yang telah dilakukan oleh Hermawan Sulistyo dalam buku Palu Arit di Ladang Tebu: Sejarah Pembantaian Massal yang Terlupakan. (Re)konstruksi sejarah juga diupayakan oleh pendukung New Social History yang, studied large numbers of ordinary people, archives with entirely new questions and needs; dengan demikian, sejarah dilihat bukan dari atas ke bawah, melainkan dari bawah ke atas.

Kegiatan pengarsipan harus juga turut berperan dalam mendidik publik. An earlier study noted that 'personal engagement with history marks a fruitftl path toward self-knowledge (Jo Pugh 1992: 21).

Karena itu, untuk mendapatkan pemahaman sejarah-dan karenanya pemahaman diri-yang baik, pengelolaan arsip harus mampu menampung berbagai informasi dari sudut pandang yang bervariasi. 


\section{DaFTAR ACUAN}

Amsyah, Zulkifli (1995), Manijemen Kearsipan. Jakarta: PT Gramedia Pustaka Utama.

Foucault, Michel (1992), "Truth and Power," dalam Adams Hazard (ed.), Critical Theory Since Plato. Orlando, Florida: Harcourt Brace Javanovich College Publishers.

Jo Pugh, Mary (1992), Profiding Reference Services for Archives and Manuscript. Illinois, Chicago: Society of American Archivist.

Kompas, 16 Februari 2000, "Untuk Cari Dokumen Asli Supersemar ANRI Akan Temui M. Yusuf dan Soeharto."

Kompas, 17 Maret 2000, "Berburu Supersemar yang Misterius."

Kompas, 5 Mei 2001, "Wapres Akan Bantu Temukan Dokumen Asli Supersemar."

O'Toole, James M. (1990), Understanding Archives and Manuscripts. Illinois, Chicago: Society of American Archivist.

Posner, Ernst (1972), Archives in the Ancient World. Cambridge, Massachusetts: Harvard University Press.

Qodari, Muhamad (2000), "Restorasi Sebuah Memori," Forum, 27 Agustus.

Ratnawati, Shinta (2002), "Menyelamatkan Arsip, Upaya Melindungi Saksi Sejarah," makalah Seminar Transisi Demokrasi di Indonesia dalam Arsip, The RIDEP Institute dan The Ford
Foundation.

Robins, Kevin (t.t., t.p.?), "What in the World's Going On."

Taylor, Hugh (1988), "My Very Act and Deed": Some Reflections on the Role of Textual Records in the Conduct of Affairs," American Archivist, Vol. 51. Thompson, Kenneth (ed.) (1997), Media and Cultural Regulation. London: Sage Publication \&
The Open University Press.

Tobing, Maruli (2001), "Jenderal Soeharto Menuju Takhta Kekuasaan," Kompas, 13 Agustus.

Wijayanta, Hanibal W. Y. (2000), "Teka-teki Hilangnya Dokumen Pak Nas," Forum, 24 Sep-
tember. 